Article

\title{
Verification Systems and Programs in Regional Television Stations That Are Members of the CIRCOM Network
}

\author{
José Rúas-Araújo *, Talía Rodríguez-Martelo (D) and Carmen Máiz-Bar (D) \\ Department of Audiovisual Communications and Advertising, School of Social Sciences and Communication, \\ University of Vigo, 36005 Pontevedra, Spain; talia.rodriguez@uvigo.es (T.R.-M.); maizbar@uvigo.es (C.M.-B.) \\ * Correspondence: joseruas@uvigo.es
}

\begin{abstract}
Disinformation and the proliferation of fake news are global problems that affect the stability of democracies throughout the world. The capacity of distorted information to interfere in election processes or in political agendas has led different actors to create verification initiatives, which operate in partnership with the mass media. Recently, during the 2020 health crisis, false information has proved to have damaging power not only at the levels of politics or communication, but also at a health level. Therefore, the social need to access reliable and quality information, as well as verified information aimed at eradicating hoaxes, becomes evident. This paper focuses on the European context, analyzing the relationship between active verifiers and television stations that are members of the CIRCOM Network, considering their strategies and verification programs. Using a qualitative methodology an exploratory study has been carried out, mapping initiatives and stations by assessing their contribution of verified information to society.
\end{abstract}

Keywords: verification; television; fake-news; CIRCOM; Europe

Citation: Rúas-Araújo, José, Talía Rodríguez-Martelo, and Carmen Máiz-Bar. 2022. Verification Systems and Programs in Regional Television Stations That Are Members of the CIRCOM Network. Journalism and Media 3: 1-12. https://doi.org/ 10.3390/journalmedia3010001

Academic Editors: Lluís Codina and Andreu Casero-Ripolles

Received: 30 September 2021 Accepted: 15 December 2021

Published: 22 December 2021

Publisher's Note: MDPI stays neutral with regard to jurisdictional claims in published maps and institutional affiliations.

Copyright: (c) 2021 by the authors. Licensee MDPI, Basel, Switzerland. This article is an open access article distributed under the terms and conditions of the Creative Commons Attribution (CC BY) license (https:// creativecommons.org/licenses/by/ $4.0 /)$.

\section{Introduction}

The proliferation of disinformation has become one of the main concerns of societies, mass media and governments in most countries worldwide. The speed with which fake information is shared, and its damaging power, have encouraged mass media to develop strategies and programs focused on information verification, in order to protect our society against this trend, as well as to protect themselves, due to the lack of trust that the massive spread of disinformation is causing. In this sense, publicly-owned media have considered this battle a building block due to their nature as a public service. TV has proven to play an indispensable role in the recent health crisis, being one the most important screens on which to follow the latest news (Casero-Ripollés 2020). This paper analyses this reality, focusing on the European regional media members of the CIRCOM Network and identifying contents and programs devoted to tackling the need for the verification of information. Registered since May 1995 as an Association at the Court of Strasbourg, the CIRCOM network is an entity that brings together most of the regional television stations all around Europe. Its main goals are to defend the public service media and to coordinate this unique network, in order to enhance promotion and communicate more efficiently. Today, 30 countries are represented ( 29 members and one associate member). Approximately 300 stations use the CIRCOM network for knowledge sharing, co-production and program exchange for better practice in communication (CIRCOM 2021). The lack of studies focused on this type of broadcaster has led this research to consider the CIRCOM network as an interesting object of study given the relationship between these entities and society. Furthermore, the importance of regional TV at a local level and its link to the community is absolutely essential in the development of public service media, mainly in the context of the fight against disinformation, which is the primary approach of this research. 


\section{Background}

\subsection{Disinformation within the European Political Context}

Disinformation can seriously damage people's life, health and finance, as well as democracy itself. Examples such as Brexit, attempts to manipulate and interfere in different national election processes, the rise of populism or the recent Coronavirus crisis have exposed the vulnerability of the European project and the weakness of the European public sphere, and fueled the discussion about the public need for protection against hoaxes and misinformation.

Disinformation can severely affect social stability, pacific coexistence and even the foundations of western democracies, embodied in the trust that citizens confer upon their public representatives and institutions. In this regard, the role of verification journalism stands out as crucial for accountability to society, and is linked to the trust in the government and public administrations, human rights and the pillars of the welfare state (Rodríguez Pérez 2020).

The European Commission defined disinformation (European Commission 2018a; Ireton and Posetti 2018) as any kind of false, inaccurate (Orso et al. 2020) or misleading information that is intentionally presented and disseminated to cause public harm or for economic gain. Furthermore, online disinformation is described as algorithms driven by the big platforms' business models, which privilege sensational content most likely to be shared among users. The document also highlights that "algorithms indirectly heighten polarisation and strengthen the effects of disinformation" (European Commission 2018a, p. 5).

A year before the May 2019 European election, and as a consequence of the continuous attacks taking place on the election processes of several countries, the European Commission (2018b) issued a series of recommendations to secure free and fair European elections as they gathered in their Salzburg meeting.

Similarly, the UN and the OSCE issued a "Joint Declaration on freedom of expression, fake news, disinformation and propaganda". All this was aimed at developing a culture of safety in our society and at increasing digital awareness and literacy, in line with the goals set by the European Union Agency for Network and Information Security (ENISA).

EU countries have also agreed to act together and start an ambitious "Action Plan On Disinformation" (European Commission 2018c), which is coordinated and, as in Spain, is directly linked to national defense and security strategies, providing an idea of the scale of the problem.

Previously, the European External Action Service (EEAS) was created in 2015, when the East StratCom Team was implemented, the "EU vs. Disinfo" platform (EUvsDisinfo 2018). This project is mainly focused on detecting and responding to disinformation campaigns coming from Russia, which aim to destabilize and interfere with issues related to the European Union member states or any other European country.

Other prominent players in the geopolitical battle against disinformation include the transatlantic initiative Alliance for Securing Democracy (part of the influential think tank German Marshall Fund), Kremlin Watch (headquartered in Prague) and the Beacon Project, which is within the International Republican Institute. All of these are active in Brussels, and well connected to EEAS, NATO and the European institutions.

In any case, information regarding European affairs has traditionally been scarce and fragmented (García-Gordillo 2012), which has enabled the construction of Eurosceptic visions (De Vries 2018).

Prior to the aforementioned European Commission paper on tackling disinformation, the only element praising pluralism was the Charter of Fundamental Rights of the European Union, which was used as the foundation for a Code of Practice against Disinformation (European Commission 2018a), supported by large technological companies such as Google, Microsoft and Twitter. Nevertheless, its real impact on the activities of those corporations is still to be determined (Fajardo-Trigueros and Rivas de Roca 2021).

Another measure implemented was the creation, in 2018, of a group of experts to tackle disinformation, where verification or fact-checking platforms play an important role 
(Palau-Sampio 2018). The foundation of the private sector project "FactCheckEU" in 2019 was an outcome of this work group.

Other examples of best practices are "How to spot when news is fake" (European Parliament 2019), which includes recommendations to detect false information and manipulated Facebook accounts; or, before Brexit, the blog Euromyths, intended to fight hoaxes spread by Eurosceptics in the United Kingdom.

Later on, and after several attempts to interfere in different regional and national election processes in Europe, the European Commission directly accused Russia of using an ad hoc "hybrid threat" to destabilize democratic processes using disinformation (Albisu 2018).

Over the past years, many institutional reports have highlighted the need to implement policies to fight disinformation, mainly via so-called "information literacy", through initiatives driven by the European Council (Wardle and Derakhshan 2017; Chapman and Oermann 2020).

More recently, in June 2020, the European Digital Media Observatory (https: / / edmo.eu, accessed on 10 December 2021) was created, linking university research groups and opinion leaders with the objective of limiting disinformation in the EU and protecting democratic integrity in election processes (Reyero and Martín 2021). Hence, within the European Commission there is a clear notion of the fact that disinformation can harm democracy (High-Level Expert Group on Fake News and Disinformation 2018; European Commission 2018a).

\subsection{Audiovisual Disinformation}

The classic sentence "a picture tells a thousand words" is becoming one of the mantras surrounding the generation and spreading of disinformation. The trend is growing, given that images have a prominent role in our information society, due to their omnipresence and capacity to trigger diverse reactions.

The current disinformation crisis is causing an important increase in the mistrust of the population towards public information in general (Alfonso et al. 2021), with politics being the field that generates the most doubts among citizens.

The politicization of information is more frequent in countries within the Mediterranean or Polarized Pluralism Models, the media system in which Spain is included according to the classification created by Hallin and Mancini (2004), with greater government intervention, influence and control of the political sphere over the media (Narberhaus et al. 2021).

In addition, the mass media are constantly forced to take a stand with strong editorial policies, in order to retain their audience percentages in an environment where information neutrality is punished. A marked trend towards exposure and selective perception leads to a less professionalized media system, as compared to the Northern European countries, which are closer to the Liberal Model (Maria López-Rico et al. 2020).

Furthermore, the global data on mistrust, which the Reuters Institute Digital News Report issues periodically, show that only $38 \%$ of the survey respondents trust the news, representing a fall of four percentage points since 2019 (Newman et al. 2021). In 2020, 67\% of the survey respondents consumed news in video format weekly, and, although in general they still preferred to read the news, more than one third of responders would rather watch it, and one out of ten to listen to it (Newman et al. 2021). These figures show a progressive increase in the interest in audiovisual information, as compared to textual information.

Moreover, despite the fact-checking efforts deployed by information companies and specialized agencies to tackle fake news and disinformation (Vázquez-Herrero et al. 2019), data from present fact-checking agencies proves that hoaxes and disinformation use audiovisual materials more frequently to support their messages, as stated by Rodríguez-Serrano et al. (2021).

In any event, international agencies are also part of the so-called "ventriloquist effect" (Civila et al. 2021) and the ethnocentric bias caused by the fact that several media (facing staffing cuts and unable to send correspondents to many countries) use either one single or very few sources, generating the concentration, convergence and omission of specific topics 
in the public agenda. This hinders the contrasting of information and multiplies unverified information, highlighting the importance of regional media associations such as CIRCOM in creating their own fact-checking networks in order to compete with disinformation.

On the other hand, the difficulty of the relationship between truth and image from the fact-checking point of view is also relevant, given that verifying an image always means partially judging its focus and contents, provided that its recipients may become prosumers and edit or reappropriate it.

Every photograph is an interpretation, no image can be considered objective and pure images do not exist. Technology is part of the new so-called post-photography scenario (Foncuberta 2016). Thus, if analogue photography was linked to truth and objectivity, digital photography - and therefore all images generated by new computer media-is linked to cynicism, manipulation and lies (Rodríguez-Ferrándiz and Sorolla-Romero 2021). Images linked to post-truth create a new geopolitical order, and may affect the democratic stability of a country or region, when hoaxes, lies and misinformation are disseminated.

The manipulation of still and moving images garners more media coverage than the generation of new content, as well as originating more social media interactions (PérezDasilva et al. 2020). This kind of content is of a diverse nature, ranging from humorous memes for entertainment purposes to false information spread widely to intentionally cause damage (Brennen et al. 2020). Additionally, as Apuke and Omar (2021) have recently stated, the increasing disinformation disseminated by social media users during the pandemic was motivated by the altruistic impulse to share significant information. This is causing new confrontations in the battle to dominate digital storytelling (Gómez-de-Ágreda et al. 2021), taking advantage of the superficiality of attention and judgement of a population that is overloaded with information.

Manipulation techniques are advancing through the use of deep-fakes, as well as modifying images and videos through advanced persistent manipulators (APMs), defined as an act or combination of actors that launch a wide, sophisticated, multimedia and multiplatform information attack on a specific target (Watts 2019), for reasons that range from influencing audiences to discrediting an enemy, causing conflicts or distorting reality. This is achieved using artificial intelligence (IA), detection algorithm training, virtual reality (VR) and augmented reality (AR) to heighten the deception (Miller 2020).

However, both traditional and new media have started to innovate in their audiovisual and sound contents when fighting disinformation. Likewise, fact-checkers seek to educate and mobilize audiences with attractive, understandable and potentially viral formats, from the stations where disinformation is circulating.

A study of the fact-checkers that are members of the International Fact-Checking Network (IFCN) shows a constant increase in the number of verifiers that distribute their contents via YouTube, a growing tendency similar to the rise in the number of published videos. Specifically, more than half of these distribute their videos via YouTube, and, in the case of the 15 fact-checkers with the highest degree of activity regarding generation and distribution, $73.3 \%$ of them link together their channels or playlists (Ramahí-García et al. 2021). In addition, more than half of the verifiers have their own social network profiles and all of them have Twitter channels. In the battle to adapt to new media, verifiers even have secondary channels in Pinterest, Flicker, Dailymotion or Flippboard, as well as a great variety of formats ranging from creative video editing, gamification, graphic posters and infographics, memes and animated gifs, TikTok videos and podcast channels on Spotify.

WhatsApp has become the network through which the population receives the most suspicious content (Resende et al. 2019), especially in Spain (Alfonso et al. 2021), the European country where that app is most frequently used to search for information, according to the Reuters Digital News Report (Newman et al. 2021) ${ }^{1}$. Bearing this in mind, some verifiers, such as Maldita.es, have included since March 2021 a new marker in their database for messages flagged as Frequently Forwarded (FF), indicating that these have been forwarded via WhatsApp five or more times, tagging them as "Highly Forwarded Messages" (HFMs). 


\section{Methodology}

The goal of this paper is to identify and monitor the existing verification initiatives and programs in stations belonging to the CIRCOM network. The research includes an exploratory study, which, using secondary sources and specialized databases, leads to a mapping of the current collaboration situation between the active verification initiatives in different European countries and regional television stations. The article has a methodological, qualitative approach based on the case study of the verification contents of the channels in the CIRCOM network. The first goal is to identify existing verification programs and initiatives in the selected stations, considering those that are members of the CIRCOM Network listed in the "Members" section of its website (European Association of Regional Television 2021).

Qualitative information is retrieved from the empirical verification of the relationships between the broadcasts of the different stations, the existence of verification programs and the nature and main features of those programs. The information is collected from the interactive databases of CIRCOM (European Association of Regional Television 2021), IFCN (2021) and the Duke Reporter's Lab (2021), where all the active verification initiatives per country are listed, as well as the countries that are members of the CIRCOM Network and the regional television stations in each territory. The information resulting from the cross-referencing of those variables has been included in a table, according to the following parameters:

1. Country

2. Television station

3. Name of the program or collaboration

4. Description of the contents

\section{Results}

Mass media, institutions and governments throughout the world have frequently expressed their concerns about the spread of disinformation, due to the damage that it can cause to the stability of democracy and to society in general. In the case of the CIRCOM members, given that the regional stations are publicly owned, they cannot simply play a secondary role in this battle against disinformation.

The commitment of these public media was reflected in 2019, when CIRCOM organized the workshop "Fake News and Verification", held in Rome. Media representatives and journalists from Bulgaria, Germany, Italy, the Czech Republic, France, Malta, Serbia, Catalonia and Galicia participated in the training session (López-Cepeda et al. 2019).

In this context, and bearing in mind the extent of the disinformation problem, whose severity was increased during the recent pandemic situation (Costa-Sánchez and LópezGarcía 2020), thus demonstrating the vulnerability of our society when facing the infodemic (Aleixandre-Benavent et al. 2020), public stations provide in their territories several verification mechanisms, sections and programs, either created by them or in collaboration with existing fact-checking initiatives.

The member stations of the CIRCOM Network have declared in their statutes and codes of practice that information verification and fighting disinformation is one of their guiding principles, as well as one of the main goals in their current agenda. Furthermore, as public regional media, their strategic development promotes a close relationship with local audiences, and therefore their capability of directly influencing the wellbeing of different geographical areas (European Association of Regional Television 2021).

After the identification of the programs and the information verification resources of the different regional stations in each member country, the results of the analysis have been included in the following table, Table 1 : 
Table 1. Programs and Information Verification Resources in CIRCOM Stations.

\begin{tabular}{|c|c|c|c|}
\hline Country & Station & $\begin{array}{l}\text { Verification Programs } \\
\text { or Collaborations }\end{array}$ & Description \\
\hline Albania & RTSH & Not reported & \\
\hline Austria & ORF & Fakt oder Fake & $\begin{array}{c}\text { TV program, general content } \\
\text { https://tv.orf.at/faktoderfake/index.html } \\
\text { (accessed on } 10 \text { December 2021) }\end{array}$ \\
\hline Belgium & RTBF (2019) & Faky & $\begin{array}{c}\text { Interactive platform to check the reliability } \\
\text { of information } \\
\text { https:/ / faky.be/fr (accessed on } \\
10 \text { December 2021) }\end{array}$ \\
\hline $\begin{array}{l}\text { Bosnia and } \\
\text { Herzegovina }\end{array}$ & BHRT & Not reported & \\
\hline Bulgaria & BNT & Not reported & \\
\hline Croatia & HRT & Not reported & \\
\hline Czech Republic & $\mathrm{CT}$ & Not reported & \\
\hline Denmark & TV2 & Not reported & \\
\hline Finland & Yle & Not reported & \\
\hline France & $\begin{array}{c}\text { FRANCE } \\
\text { TELÉVISIONS }\end{array}$ & $\begin{array}{c}\text { WTKake? } \\
\text { Coronavirus } \\
\text { La fabrique du mesonge }\end{array}$ & $\begin{array}{c}\text { Humorous program of general content } \\
\text { based on popular disinformation } \\
\text { https:/ / www.france.tv / slash/wtfake/ } \\
\text { (accessed on 10 December 2021) } \\
\text { Special program about COVID-19 } \\
\text { broadcasted on March 2021 Documentary } \\
\text { series with two seasons, general content } \\
\text { https:/ / www.france.tv / france-2/ } \\
\text { coronavirus-posez-vos-questions/ } \\
\text { https:/ / www.france.tv / france-5/la- } \\
\text { fabrique-du-mensonge/ (accessed on } 10 \\
\text { December 2021) }\end{array}$ \\
\hline \multirow[t]{2}{*}{ Germany } & HR & Not reported & \\
\hline & RBB & Not reported & \\
\hline Greece & ERT3 & Not reported & \\
\hline Hungary & MTVA & Not reported & \\
\hline \multirow[t]{2}{*}{ Ireland } & RTÉ & Truth matters & $\begin{array}{l}\text { Series and podcasts with several episodes, } \\
\text { about disinformation and its consequences } \\
\text { https:/ / www.rte.ie/ eile/truth-matters / } \\
\text { (accessed on } 10 \text { December 2021) }\end{array}$ \\
\hline & TG4 & Not reported & \\
\hline Italy & RAI & Not reported & \\
\hline $\begin{array}{c}\text { North } \\
\text { Macedonia }\end{array}$ & MKRTV & Not reported & \\
\hline Montenegro & RTCG & Not reported & \\
\hline $\begin{array}{l}\text { The } \\
\text { Netherlands }\end{array}$ & Stichtig PRO & Not reported & \\
\hline Norway & NRK & Faktisk & $\begin{array}{l}\text { Cooperation Project involving several } \\
\text { stations, NRK among them } \\
\text { https://www.faktisk.no/ (accessed on } 10 \\
\text { December 2021) }\end{array}$ \\
\hline Poland & TVP & Not reported & \\
\hline Portugal & RTP & Not reported & \\
\hline Romania & TVR & Not reported & \\
\hline \multirow{2}{*}{ Serbia } & RTS & Not reported & \\
\hline & RTV & Not reported & \\
\hline Slovakia & RTVS & Not reported & \\
\hline Slovenia & RTVSLO & Not reported & \\
\hline
\end{tabular}


Table 1. Cont.

\begin{tabular}{|c|c|c|c|}
\hline Country & Station & $\begin{array}{l}\text { Verification Programs } \\
\text { or Collaborations }\end{array}$ & Description \\
\hline \multirow{11}{*}{ Spain } & CRTVG & "Coidémonos" & $\begin{array}{l}\text { Institutional Initiative to fight against } \\
\text { Disinformation about COVID-19 }\end{array}$ \\
\hline & ЕITB & $\begin{array}{l}\text { Coronabulos, } \\
\text { inFORMAZIOA }\end{array}$ & $\begin{array}{l}\text { Special program about disinformation } \\
\text { linked to Coronavirus. } \\
\text { Focused on media literacy. }\end{array}$ \\
\hline & EPRTVIB & Balears fa Ciència & $\begin{array}{l}\text { Educational program that broadcasted an } \\
\text { episode on Fake News and Coronavirus, } \\
\text { cooperating with Maldita and Newtral }\end{array}$ \\
\hline & RTPA & $\begin{array}{l}\text { Salud Asturias Especial } \\
\text { COVID-19 }\end{array}$ & $\begin{array}{l}\text { Program about fake news linked to } \\
\text { the pandemic }\end{array}$ \\
\hline & RTVCyL & Not reported & \\
\hline & CARTV & Not reported & \\
\hline & CCMA & Fets ou Fakes & $\begin{array}{l}\text { Podcast and tool managed by journalists } \\
\text { who are part of the news sections within } \\
\text { Catalunya Radio }\end{array}$ \\
\hline & RTRM & Not reported & \\
\hline & CEXMA & Not reported & \\
\hline & $\mathrm{CMM}$ & Bulos del Coronavirus & $\begin{array}{l}\text { Website section focused on reporting fake } \\
\text { news linked to Coronavirus } \\
\text { https://www.cmmedia.es/tag/bulos-del- } \\
\text { coronavirus / (accessed on } \\
\text { 10 December 2021) }\end{array}$ \\
\hline & Telemadrid & Not reported & \\
\hline Sweden & SVT & Not reported & \\
\hline Switzerland & RSI & Not reported & \\
\hline United Kindom & $\mathrm{BBC}$ & Reality Check & $\begin{array}{l}\text { Special section in news programs } \\
\text { https: } \\
\text { / / www.bbc.com/news/reality_check } \\
\text { (accessed on } 10 \text { December } 2021 \text { ) }\end{array}$ \\
\hline
\end{tabular}

Source: Prepared by the authors with information from European Association of Regional Television (2021), IFCN (2021) and the Duke Reporter's Lab (2021).

Currently, the CIRCOM Network, or European Association of Regional Television, has members from 29 countries and 43 stations, of which 11 have programs or collaborations focused on information verification. These contents are aimed at curbing the spread of disinformation and keeping their audiences informed about hoaxes on the internet and social media. Although several programs or special TV sections focused on Coronavirus were released during the pandemic, content aimed at fighting against disinformation have been frequently launched within the last five years. This content does not follow a common style or pattern-humorous content, info shows or serious TV news approaches are included. With substantial differences in the presentation format, all the indicators in the TV programs and initiatives analysed operate in order to prove whether certain information is true or false, whether with a red-green scale, using the aesthetic appeal of a thermometer or a simply semantic categorization.

Albania, the first country analyzed, does not seem to have any television content about verification when exploring the scheduled programs of their regional station. Nevertheless, there was a collaboration between OSCE and the European Broadcasting Union about job training in the RTSH station, where acquiring skills to verify information and identify misinformation was included (OSCE 2017).

In Austria, the regional station ORF has its own program, called "Fakt oder Fake", with general content, a host and several experts in different disciplines. In the case of Belgium, when exploring the website of their station RTBF, many articles and contents focused on disinformation can be found. The station has developed an interactive tool, 
Faky, where citizens can check the reliability of their information by typing the links of the websites in question into the platform.

France is one of the countries with the largest number of information verification initiatives, as well as television and radio contents focused on finding and fighting disinformation, either related to politics or in general. Many of these initiatives are linked to mass media, and some are the joint projects of journalists from different stations. Examples are the weekly program "Vrai ou Fake", based on information that has been verified by assorted public broadcasters in France (Duke Reporter's Lab 2021). As for the regional station France Televisions, three programs specifically focus on fake news and content verification: "La fabrique du mensonge", about the spread and effects of disinformation; "WTFake?", about online hoaxes and "Coronavirus", about the recent health crisis.

Although most regional stations have articles, information or rebuttals about disinformation, or provide tools to discredit these on their websites, not all of them offer specific sections to explore this issue or television contents that would help to bring it to their audiences. Nevertheless, it is possible to find, in every country within the Network, initiatives promoted by mass media or organizations that independently provide verification tools.

In the case of Ireland, two of their regional stations are members of CIRCOM: RTÉ and TG4. RTÉ produces a series, with different episodes and a podcast, about the consequences of disinformation in our current society. Their news section is considered one of the most reliable sources by the Irish citizens. The participation of RTÉ News in the "Journalism Trust Initiative" and their cooperation with Reporters Without Borders, in partnership with the European Broadcasting Union and the World Association of News Publishers, represent the origins of that content (Williams 2021).

As for Bosnia, Croatia, Denmark, Finland, Italy, the Czech Republic and Germany, according to the databases found at the Duke Reporter's Lab (2021) and IFCN (2021), several independent media- or journalist-related initiatives are active, but television content was not found in all the stations. Many public stations broadcast independent sections, or include information regarding verification in their news sections.

Another frequent method through which television stations fight disinformation is their participation in joint projects, together with other mass media representatives. Such is the case with NRK in Norway, with their project Faktisk, in which VG, Dagbladet, NRK, TV2, Polaris Media and Amedia are participants.

Portugal has two verification initiatives: Polígrafo and Observador, the latter linked to the digital newspaper. Both of them have their own programs in the SIC and TVI stations, and their focus is on the verification of information related to politics. Nevertheless, RTP does not include any specific programs or sections focusing on false information or fact-checking.

Interestingly, fact-checking and its presence in the media agenda is not recent. However, many stations had not previously deployed all their resources in developing contents devoted to verification. The Coronavirus pandemic has forced society to focus on this issue, and it is currently possible to find specific sections on this subject on every station and their websites, very often providing information about fake news and verified information.

Spain is the CIRCOM member with the largest number of regional stations, numbering a total of eleven. The Galician television station CRTVG created an institutional campaign called "Coidémonos" (Let's take care of ourselves) to prevent disinformation related to the pandemic (CRTVG 2020). The Basque television station EITB has a weekly section devoted to warning the population about disinformation; a specific educational program, "inFORMAZIOA", about detecting false information and the initiative "Coronabulos" (Coronahoaxes), through which citizens can submit suspicious information to be verified. The Catalonian television station CCMA has created "Fets o Fakes" (Facts or fakes), a podcast about disinformation that is also a fact-checking tool for its audience, who can send in data for verification. The Castilian television station CMM has included a section on its website dedicated to compiling fake news related to Coronavirus. Telemadrid, the regional television station in Madrid, also has a fake news-specific section on its website, 
and frequently mentions this issue in its newscasts, particularly when false information has gone viral; nonetheless, there are no specialized television programs about this topic.

Regarding joint programs and initiatives, the organization that encompasses all Spanish regional television stations, Federación de Organismos de Radio y Televisión (FORTA), has been running campaigns for years, educating their audiences about how to act when faced with disinformation. In 2019, they launched a global campaign named "Fake News: si dudas, no compartas" (Fake news: in case of doubt, do not share), a decalogue of best practices aimed at providing guidance to identify and not to share false information (CARTV 2019).

In essence, the analysis of the stations belonging to the CIRCOM Network includes fourteen sections, programs or initiatives specifically focused on disinformation or information verification. Of these, four are specialized in information about COVID-19, while the rest deal with disinformation in different areas and from different sources.

\section{Discussion and Conclusions}

Disinformation is a global problem, affecting all countries simultaneously. It is also highly difficult to eradicate, given the nature of shared false information, its viral potential and the agility of social and mass media in a digital environment.

Most governments have stated that fake news is one of their main problems, due to its capacity to interfere with democratic processes. Furthermore, the recent health crisis and the proliferation of false information-the so-called infodemic-have confirmed the dangers of consuming disinformation and the need to train citizens on data verification in order to protect them from hoaxes.

Alongside governments, the mass media have expressed their concern about this issue, and have carried out several actions to mitigate the proliferation of disinformation. Their crucial role in the informative structure of our society holds them accountable for offering accurate and reliable information to their audiences. In this respect, publiclyowned media must protect the integrity of information, and guarantee the access of all citizens to that information.

These matters, covered in most mass media guidelines, are also shared by regional media. In the case of the regional stations that are members of the CIRCOM Network, their scope of action in the different European countries makes their role equally relevant-or even more so, due to the proximity of local media to their audiences.

Both in the jointly undersigned principles and in the guidelines developed by each of the stations belonging to the European Association of Regional Televisions, fighting disinformation is a focal point. This is reflected in our content analysis, given that almost every radio and television station includes information about fake news on their websites. Nevertheless, we could only identify eleven stations, with fourteen programs or initiatives that focus on information verification, out of the 43 stations that are members of the CIRCOM Network.

The presence of specific sections and contents increased due to the COVID-19 health crisis, as several sections and data found through our mapping process covering websites and programs of each station in the CIRCOM Network are focused on Coronavirus and its related hoaxes, and their intention is to warn the general population against them. Several news programs whose goal was to provide audiences with tools were also identified, seeking to empower and train them in information verification, thus reducing any possible risks.

Despite all this, the amount of specific content is still small, and the lack of radio and television programs make the search for and verification of information mostly dependent on the proactivity of the audiences. Considering that the reception of falsehoods is passive, and due to it arriving from several sources, public media should prioritize fighting its massive spread, creating content focused on information, reflection and education, and turning verification into a joint task, in which both media and society participate. 


\begin{abstract}
Author Contributions: Conceptualization and methodology, J.R.-A.; formal analysis, investigation, resources, and data curation, T.R.-M.; writing-original draft preparation, writing-review and editing, C.M.-B. All authors have read and agreed to the published version of the manuscript.
\end{abstract}

Funding: The results of this article are part of the research activities promoted through the research project PDC2021-121720-I00 of the State Program of R+D+i Projects Proof of Concept 2021 of the Ministry of Science, Innovation and Universities financed by the European Union through NextGenerationEU funds for the "Fight against disinformation and value criteria in electoral debates on television and digital media: verification platform and blockchain."

Conflicts of Interest: The authors declare no conflict of interest.

\title{
Notes
}

1 https://www.digitalnewsreport.org/survey/2021/ (accessed on 21 September 2021).

\section{References}

Albisu, John A. 2018. La Comisión Europea Ultima un Sistema de Detección Rápida de Noticias Falsas. ABC. December 5. Available online: https:/ / www.abc.es/tecnologia/redes/abci-comision-europea-ultima-sistemadeteccion-rapida-noticias-falsas-201812 051717_noticia.html (accessed on 2 September 2021).

Aleixandre-Benavent, Rafael, Lourdes Castelló-Cogollos, and Juan-Carlos Valderrama-Zurián. 2020. Información y comunicación durante los primeros meses de Covid-19. Infodemia, desinformación y papel de los profesionales de la información. Profesional de la información 29: e290408. [CrossRef]

Alfonso, Ignacio Blanco, María Ángeles Chaparro Domínguez, and Rafael Repiso Caballero. 2021. El fact-checking como estrategia global para contener la desinformación. Estudios Sobre el Mensaje Periodístico 27: 779-91. [CrossRef]

Apuke, Oberiri Destiny, and Bahiyah Omar. 2021. Fake news and COVID-19: Modeling the predictors of fake news sharing among social media users. Telematics and Informatics 56: 101475. [CrossRef] [PubMed]

Brennen, J. Scott, Felix M. Simon, Philip N. Howard, and Rasmus Kleis Nielsen. 2020. Types, Sources, and Claims of COVID-19 Misinformation. Oxford: Reuters Institute for the Study of Journalism, April 7. Available online: https://reutersinstitute.politics. ox.ac.uk/types-sources-and-claims-covid-19-misinformation (accessed on 4 September 2021).

CARTV. 2019. Lucha Contra las Fake News. Aragón Sostenible. January 1. Available online: https://www.cartv.es/aragonsostenible/ canal-ods/luchas-contra-las-fake-news (accessed on 28 August 2021).

Casero-Ripollés, Andreu. 2020. Impact of COVID-19 on the media system. Communicative and democratic consequences of news consumption during the outbreak. The Professional of the Information 29: e290223. [CrossRef]

Chapman, Martina, and Markus Oermann. 2020. Supporting Quality Journalism through Media and Information Literacy. Strasbourg: Council of Europe. Available online: https:/ / edoc.coe.int/fr/medias/8264-supporting-quality-journalism-through-media-andinformation-literacy.html (accessed on 27 August 2021).

CIRCOM. 2021. About Circom Regional. Available online: https://www.circom-regional.eu/about-circom-3/about-circom-1 (accessed on 27 September 2021).

Civila, Sabina, Bárbara Castillo-Abdul, and Luis Miguel Romero-Rodríguez. 2021. El «efecto ventrílocuo» en las agencias internacionales de noticias. Revisión teórica e incidencia en las nuevas formas de desinformación. Vivat Academia. Revista de Comunicación 154: 25-46. [CrossRef]

Costa-Sánchez, Carmen, and Xosé López-García. 2020. Comunicación y crisis del coronavirus en España. Primeras lecciones. Profesional De La Información 29. [CrossRef]

CRTVG. 2020. As Televisións Autonómicas Activan Iniciativas Para Combater as Noticias Falsas. April 7. Available online: https:// www.crtvg.es/crtvg/noticias-corporativas/as-televisions-autonomicas-activan-iniciativas-para-combater-as-noticias-falsas (accessed on 26 September 2021).

De Vries, Catherine E. 2018. Euroscepticism and the Future of European Integration. Oxford: Oxford University Press.

Duke Reporter's Lab. 2021. Global Fact Checking Sites. Available online: https:/ / reporterslab.org/fact-checking/ (accessed on 25 September 2021).

European Association of Regional Television. 2021. CIRCOM. Available online: https://www.circom-regional.eu/ (accessed on 25 September 2021).

European Commission. 2018a. Tackling Online Disinformation: A European Approach. Available online: https://eur-lex.europa.eu/ legal-content/EN/TXT/PDF/?uri=CELEX:52018DC0236 (accessed on 7 October 2021).

European Commission. 2018b. Securing Free and Fair European Elections. Available online: https://eur-lex.europa.eu/legal-content/ EN/TXT/PDF/?uri=CELEX:52018DC0637\&from=EN (accessed on 7 October 2021).

European Commission. 2018c. Action Plan on Disinformation. Available online: https:/ /ec.europa.eu/info/publications/action-plandisinformation-commission-contribution-european-council-13-14-december-2018_en (accessed on 7 October 2021).

European Parliament. 2019. How to Spot When News Is Fake. European Parliament Research Service. Available online: https: / / www.europarl.europa.eu/RegData/etudes/ATAG/2017/599386/EPRS_ATA(2017)599386_EN.pdf (accessed on 16 August 2021). 
EUvsDisinfo. 2018. Understanding the Threat and Stepping up European Response. Available online: https://www.dsn.gob.es/es/ actualidad/sala-prensa/uni\%C3\%B3n-europea-plan-lucha-contra-desinformaci\%C3\%B3n (accessed on 16 September 2021).

Fajardo-Trigueros, Clara, and Rubén Rivas de Roca. 2021. Twitter como herramienta de alfabetización: La respuesta europea a la pandemia. In Digital Media: El Papel de las Redes Sociales en el Ecosistema Educomunicativo en Tiempos de COVID-19. Edited by Joaquín Sotelo González and Joaquín González García. Madrid: McGraw Hill, pp. 311-30.

Foncuberta, Joan. 2016. La Furia de las Imágenes. Notas Sobre la Postfotografía. Barcelona: Galaxia Gutenberg.

García-Gordillo, Mar. 2012. La información política electoral: La campaña a las elecciones al Parlamento Europeo del 7 de junio. Un estudio de caso en la prensa tradicional y digital. In Prensa y Periodismo Especializado. Edited by Juan José Fernández Sanz, Ángel L. Rubio Moraga and Carlos Sanz Establés. Guadalajara: Asociación de la Prensa, vol. 5, pp. 73-86.

Gómez-de-Ágreda, Ángel, Claudio Feijóo, and Idoia-Ana Salazar-García. 2021. Una nueva taxonomía del uso de la imagen en la conformación interesada del relato digital. Deep fakes e inteligencia artificial. Profesional de la Información 30: e300216. [CrossRef]

Hallin, Daniel C., and Paolo Mancini. 2004. Comparing Media Systems: Three Models of Media and Politics. Cambridge: Cambridge University Press.

High-Level Expert Group on Fake News and Disinformation. 2018. A Multi-Dimensional Approach to Disinformation. Report of the Independent High Level Group on Fake News and Online Disinformation. Luxemburg: European Commission, Directorate-General for Communication Networks, Content and Technology. Available online: https:/ / publications.europa.eu/en/publication-detail/- / publication/6ef4df8b-4cea-11e8-be1d-01aa75ed71a1/language-en (accessed on 16 September 2021).

IFCN (International Fact Checking Network). 2021. International Fact-Checking Network Fact-Checker's Code of Principles. Available online: https: / www.poynter.org/ifcn-fact-checkers-code-of-principles / (accessed on 16 September 2021).

Ireton, Cherilyn, and Julie Posetti. 2018. Journalism, Fake News E Disinformation: Handbook for Journalism Education and Training. Paris: Unesco.

López-Cepeda, Ana María, María-José Ufarte-Ruiz, and Francisco-José Murcia-Verdú. 2019. Medios audiovisuales de servicio público y desinformación. Principales noticias y estrategias contra las noticias falsas. In Las Nuevas Narrativas, en el Entorno Social. Edited by Actas-III Congreso Internacional Latina de Comunicación Social. Tenerife: Universidad de la Laguna, Diciembre 2, pp. 155-70. [CrossRef]

Maria López-Rico, Carmen, Jose Luis Gonzalez-Esteban, and Alberto Hernandez-Martinez. 2020. Polarization and trust in Spanish media during the COVID-19. Identification of audience profiles. Revista Española de Comunicación en Salud, 77-89.

Miller, M. Nina. 2020. Digital Threats to Democracy: A Double-Edged Sentence. Washington, DC: Technology for Global Security. CNAS Available online: https://www.cnas.org/publications/commentary/digital-threats-to-democracy-a-double-edged-sentence (accessed on 22 September 2021).

Narberhaus, Marta, Xavier Ramon Vegas, and Cristina Perales García. 2021. Rendición de cuentas de los medios en la era digital: Visiones de los periodistas y ciudadanos catalanes y propuestas de actuación. Hipertext. net: Revista Académica sobre Documentación Digital y Comunicación Interactiva 22: 8. [CrossRef]

Newman, Nic, Richard Fletcher, Anne Schulz, Simge And1, Craig T. Robertson, and Rasmus Kleis Nielsen. 2021. Reuters Institute Digital News Report 2021. Oxford: Reuters Institute for the Study of Journalism, University of Oxford. Available online: https:/ / reutersinstitute.politics.ox.ac.uk/digital-news-report/2021 (accessed on 23 August 2021).

Orso, Daniele, Nicola Federici, Roberto Copetti, Luigi Vetrugno, and Tiziana Bove. 2020. Infodemic and the spread of fake news in the COVID-19-era. European Journal of Emergency Medicine. [CrossRef] [PubMed]

OSCE. 2017. OSCE and European Broadcasting Union Train Albania's Journalists on Online Media and Social Networks. November 6. Available online: https:/ / www.osce.org/presence-in-albania/354926 (accessed on 15 August 2021).

Palau-Sampio, Dolors. 2018. Fact-checking and scrutiny of power: Supervision of public discourses in new media platforms from Latin America. Communication \& Society 31: 347-63.

Pérez-Dasilva, Jesús-Ángel, Koldobica Meso-Ayerdi, and Terese Mendiguren-Galdospín. 2020. Fake news and coronavirus: Detection of the main actors and trends through the analysis of conversations on Twitter. Information Professional 29: e290308. [CrossRef]

Ramahí-García, Diana, Oswaldo García-Crespo, and Alberto Dafonte-Gómez. 2021. Los formatos audiovisuales en la verificación de datos. Análisis de la actividad de los fact-checkers en YouTube (2009-2020). adComunica 22: 95-118. [CrossRef]

Resende, Gustavo, Philipe Melo, Julio C. S. Reis, Marisa Vasconcelos, Jussara M. Almeida, and Fabrício Benevenuto. 2019. Analyzing Textual (Mis) Information Shared in WhatsApp Groups. Paper presented at WebSci '19: 10th ACM Conference on Web Science, Boston, MA, USA, June 30-July 3; pp. 225-34.

Reyero, Eva Ramón, and Ascensión Gil Martín. 2021. Desinformación e infoxicación, dos "falsos sinónimos" frente a la estrategia de información de la Comisión Europea. Comunicación y Hombre 17: 103-18. [CrossRef]

Rodríguez Pérez, Carlos. 2020. Una reflexión sobre la epistemología del fact-checking journalism: Retos y dilemas. Revista de Comunicación 19: 243-58. [CrossRef]

Rodríguez-Ferrándiz, Raúl, and Teresa Sorolla-Romero. 2021. El análisis de las imágenes en la era de las fake news. adComunica: Revista Científica de Estrategias, Tendencias e Innovación en Comunicación 22: 23-26. [CrossRef]

Rodríguez-Serrano, Aaron, María Soler-Campillo, and Javier Marzal-Felici. 2021. Fact-checking audiovisual en la era de la posverdad. ¿Qué significa validar una imagen? Revista Latina de Comunicación Social 79: 19-42. [CrossRef]

RTBF. 2019. Faky, Nouvel Outil RTBF Pour Lutter Contre la Désinformation, Suspendu, Reviendra Dans une Version Améliorée. Available online: https:/ / cutt.ly/Krq7bWX (accessed on 7 November 2021). 
Vázquez-Herrero, Jorge, Ángel Vizoso, and Xosé López-García. 2019. Innovación tecnológica y comunicativa para combatir la desinformación: 135 experiencias para un cambio de rumbo. El Profesional de la Información 28: 1-12. [CrossRef]

Wardle, Claire, and Hossein Derakhshan. 2017. Information Disorder: Toward an Interdisciplinary Framework for Research and Policy Making. Strasburg: Council of Europe. Available online: https://rm.coe.int/information-disorder-toward-an-interdisciplinaryframework-forresearc/168076277 (accessed on 7 December 2021).

Watts, Clint. 2019. Advanced Persistent Manipulators, Part One: The Threat to the Social Media Industry. Alliance for Securing Democracy. Available online: https:/ / securingdemocracy.gmfus.org/advanced-persistent-manipulators-part-one-the-threatto-the-social-media-industry (accessed on 9 December 2021).

Williams, Jon. 2021. Why Disinformation is Poison on the Bloodstream of Society. June 23. Available online: https://www.rte.ie/eile/ truth-matters/2021/0623/1230913-why-disinformation-is-poison-in-the-bloodstream-of-society/ (accessed on 9 December 2021). 